\title{
Knowledge, Attitude and Practice towards Malaria Prevention among School Children aged 5 -14 years in Sub-Saharan Africa - A review of Literature
}

\author{
Marie Louise Umwangange ${ }^{1 *}$, Geldine Chironda ${ }^{1,2}$, Madeleine Mukeshimana ${ }^{1}$ \\ 1. School of Nursing and Midwifery, College of Medicine and Health Sciences, University of Rwanda \\ 2. New York University, New York, US \\ *Corresponding author: Marie Louise Umwangange (umwangange2008@yahoo.fr)
}

\begin{abstract}
Background: More than 500 million school children around the world are at risk of malaria infection and 200 million live in sub-Saharan Africa. One of the methods of prevention of malaria is increasing knowledge, attitude and practice of schoolchildren about malaria. Objective: The objective of this paper is to review the knowledge, attitude and practice of malaria prevention among schoolchildren in the age group of 5 to 14 years in sub-Saharan Africa. Methods: The search engines which were used to obtain the literature include databases such as PubMed, Hinari, Cinhal, Google scholar, grey literature, and manual search. The articles published between 2010 and 2016 which assessed the knowledge, attitude and/ or practice of malaria among school children were searched using the following key words: knowledge, attitude, practice, insecticide treated net, malaria, schoolchildren, sub-Saharan Africa. 14 articles were obtained. Results: Knowledge of malaria cause and transmission was ranging from $19.2 \%$ in Zimbabwe to $85 \%$ in Nigeria and the attitude was low. However the age group of the schoolchildren in two countries were different. There are still misconception of malaria cause and transmission in schoolchildren in many countries of sub-Saharan Africa. Studies showed low to moderate level of practice of malaria prevention ranging from $32.4 \%$ in Malawi to $67.9 \%$ in Kenyan schoolchildren. Conclusion: Knowledge, attitude and practice of malaria remain a problem in schoolchildren of sub-Saharan Africa. There is need for implementation of interventions that will focus on increasing the knowledge levels of malaria among schoolchildren. Altering the perceptions and attitude of schoolchildren in a positive way will enhance best practices towards malaria prevention among schoolchildren.
\end{abstract}

\section{Keywords}

Knowledge, Attitude, Practice, Malaria, Prevention, Schoolchildren, sub-Saharan Africa

\section{Introduction}

Malaria is the fourth cause of child death in sub-Saharan Africa, remaining the main killer of children in every 2 minutes.[1] There are more than 500 million school children who are at risk of getting malaria around the world and 200 million live in Sub Saharan Africa.[2] An estimated $6-9 \%$ of all malaria death was found in school children aged 5-14 years, accounting for 70,000-110,000 malaria death per year globally.[2] As children become older, they become independent and parents becomes less controlling on the time they go to bed, whether they sleep under a net or not consequently increasing their risk of getting malaria.[3]

Although there has been much focus on prevention and control of malaria from different stakeholders, African continent especially sub-Saharan region (east, west, central and southern Africa) continues to bear the greatest burden of malaria in school going children. [4] The prevalence of malaria in east African region among schoolchildren ranges from 9 to 23 percent in Tanzania to approximately 49 percent in Kenya where the age group of and age group 7-10 years was significantly associated with malaria infection $(\mathrm{p}<0.001)[1,3,5-7]$ whilst that of central Africa is between 16\% in DRC and $42 \%$ in Equatorial guinea.[8-10] Similarly, a higher prevalence rate of malaria among schoolchildren in southern Africa is in the range of $43 \%$ in Zambia and $60 \%$ in Malawi. Moreover, West African region published prevalent figures ranging from $15 \%$ in Ethiopia and 83\% in Mali.[11-14]

Despite the increase in incidence and prevalence of malaria among school going children, the literature on knowledge, attitude and practices in prevention of 
malaria remains scarce and unsynthesized. Yet, these three parameters are important in the control and prevention of malaria among school going children. Poor knowledge, negative attitude and low practices cause detrimental effects to schoolchildren. Severe falciparum malaria in children causes high fever, central nervous system problems like seizures and altered consciousness. [15] In addition, complications like renal failure, respiratory distress, severe anaemia, thrombocytopenia, hypoglycaemia, metabolic acidosis and hyperlactemia are severe detrimental effects.[16] Further, malaria is responsible for nearly $25 \%$ of all child death in subSaharan Africa[15]. Furthermore, malaria is one of the most causes of school absenteeism[3,17] as it accounts for $13-30 \%$ of the medical reasons of absenteeism from school. Moreover, malaria affects the school performance of children by reducing their test score; and this has been confirmed by numerous studies [5,6,17] which explained the consequences of malaria on cognitive function and capacity of schoolchildren.

There is high incidence and prevalence of malaria and detrimental complications in schoolchildren as shown in literature of sub-Saharan Africa.[7-10,12,13,18,19] Despite the information on malaria the school children are getting from school curriculum, their knowledge, attitudes and practice towards malaria prevention are still questionable and needs to be reviewed. Furthermore, there is no review in literature about malaria among schoolchildren in sub-Saharan Africa. Most reviews have focused on adults; hence the purpose of the review is to give an overview of the current knowledge, attitude and practice towards malaria prevention among schoolchildren in sub-Saharan Africa.

\section{Methods}

The search engines which were used to obtain the literature include databases such as PubMed, Hinari, Cumulative Index of Nursing and Allied Health (CINAHL), Google scholar, African Journals online (AJOL) and grey literature. The articles published from
2010 to 2016 which assessed the knowledge, attitude and practice of malaria prevention among school children were searched using the following key words: knowledge, attitude, practice, insecticide treated net, malaria, schoolchildren, sub-Saharan Africa and the following combinations were used: 'Knowledge' OR 'attitude' OR 'practice' AND 'malaria' AND 'school children [tab]' AND 'Sub-Saharan Africa'. 'Knowledge' AND 'attitude' AND 'practice' AND 'malaria' AND 'school children [tab]' AND 'Sub-Saharan Africa.'(Refer to figure 1)

At first search, 273 studies were obtained, following inclusion and exclusion criteria, 14 articles were identified to be included in the review. 13 Quantitative studies and 1 mixed study were screened including those which assess knowledge, attitude and practice. Those which used quasi-experimental study design and compare the knowledge, attitude and practice towards malaria prevention among schoolchildren in the age group of 5 to 14 years were also included in the review. Studies which had the results showing knowledge, attitude or practice level of malaria among schoolchildren, even though, they were not showing the key words in the title were also included. Only peer-reviewed studies written in English with the full-text which were conducted in countries located in sub-Saharan Africa were included.

Studies which were excluded are those published before 2010, studies which were conducted in adult people, those which were done in other continents, not Africa, and those conducted in other part of Africa (not subSaharan Africa) were excluded. Editorials, news and comments from people and studies with no outcome of interest were also excluded. Figure 1 reveals the search strategy. 


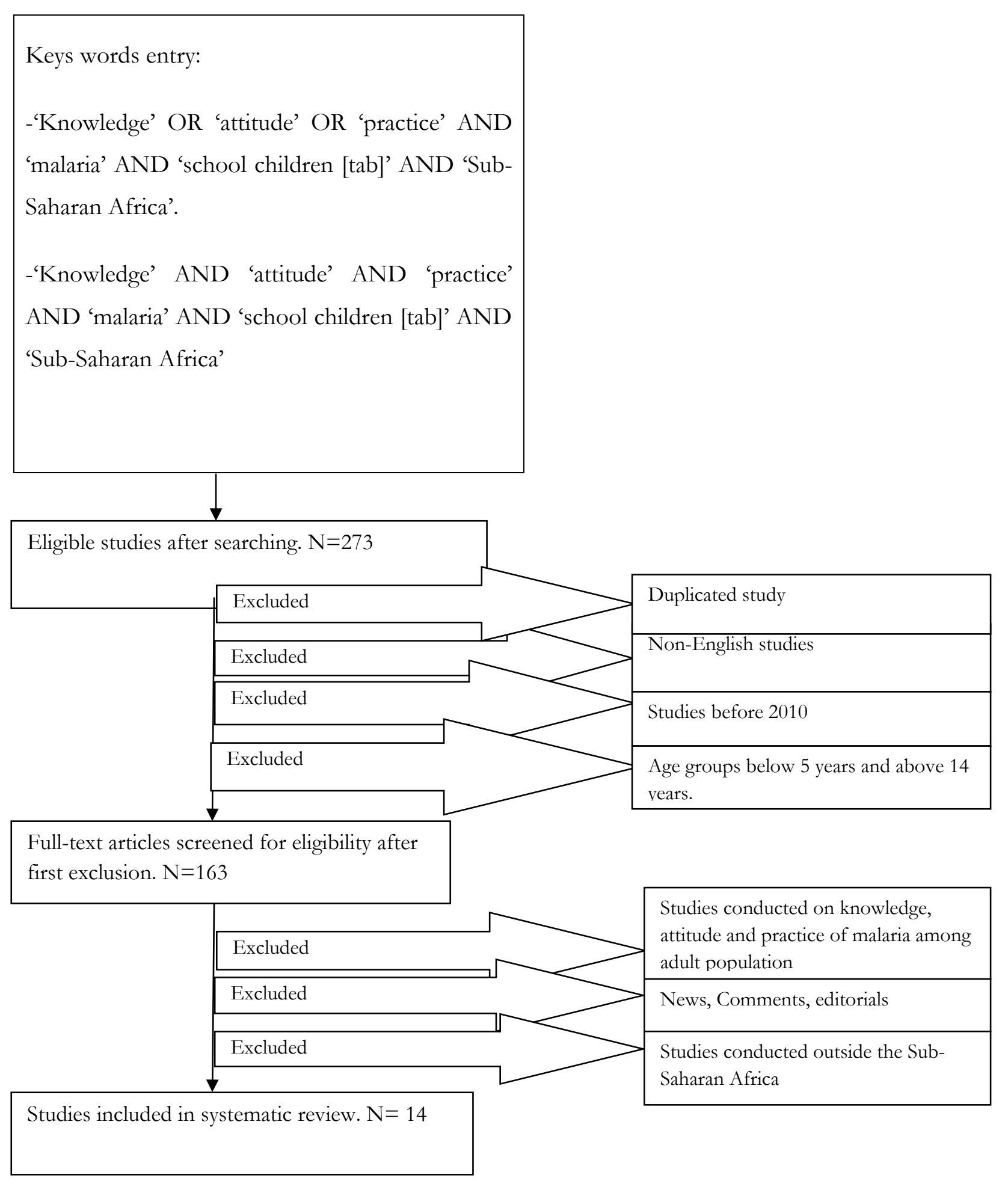

Figure 1. Diagram showing flow of searching strategy 


\section{Results and Discussion}

Table 1.Summary of the reviewed studies

\begin{tabular}{|c|c|c|c|c|c|c|}
\hline Authors & Study title and journal & Country & Study type & Study design & $\begin{array}{l}\text { Study } \\
\text { population }\end{array}$ & $\begin{array}{l}\text { Sample } \\
\text { size }\end{array}$ \\
\hline $\begin{array}{l}\text { Eko Jimmy } \\
\text { E. et al.2013 }\end{array}$ & $\begin{array}{l}\text { Practices of Malaria } \\
\text { Prevention among School } \\
\text { Adolescent within Calabar } \\
\text { Metropolis, Southern } \\
\text { Nigeria. J Sociol Res }\end{array}$ & Nigeria & Quantitative & Cross-sectional & $\begin{array}{l}\text { School } \\
\text { adolescents }\end{array}$ & 400 \\
\hline $\begin{array}{l}\text { Udonwa, } \\
\text { NE. et al. } \\
2010\end{array}$ & $\begin{array}{l}\text { Malaria: Knowledge and } \\
\text { prevention practices } \\
\text { among school adolescents } \\
\text { in a coastal community in } \\
\text { Calabar, Nigeria }\end{array}$ & Nigeria & Quantitative & Cross sectional & $\begin{array}{l}\text { School } \\
\text { adolescents }\end{array}$ & 400 \\
\hline $\begin{array}{l}\text { Sumari, } \\
\text { D.et al. } \\
2016\end{array}$ & $\begin{array}{l}\text { Knowledge, attitudes and } \\
\text { practices on malaria in } \\
\text { relation to its transmission } \\
\text { among primary school } \\
\text { children in Bagamoyo } \\
\text { district. MWJ }\end{array}$ & Tanzania & $\begin{array}{l}\text { Mixed- } \\
\text { research }\end{array}$ & $\begin{array}{l}\text { Mixed-method } \\
\text { study }\end{array}$ & $\begin{array}{l}\text { School children } \\
\text { (6-14 years) }\end{array}$ & 125 \\
\hline $\begin{array}{l}\text { Midzi et.al. } \\
2011\end{array}$ & $\begin{array}{l}\text { Knowledge attitudes and } \\
\text { practices of grade three } \\
\text { primary schoolchildren in } \\
\text { relation to schistosomiasis, } \\
\text { soil transmitted } \\
\text { helminthiasis and malaria } \\
\text { in Zimbabwe. BMC Infect } \\
\text { Dis }\end{array}$ & Zimbabwe & Quantitative & Cross-sectional & $\begin{array}{l}\text { School children } \\
\text { grade } 3 \text { (8-10 } \\
\text { years) }\end{array}$ & 172 \\
\hline $\begin{array}{l}\text { Debela Y. } \\
2013\end{array}$ & $\begin{array}{l}\text { Malaria Related } \\
\text { Knowledge and Child to } \\
\text { Parent Communication } \\
\text { Regarding Prevention and } \\
\text { Control of Malaria among } \\
\text { Primary School Students } \\
\text { in Jimma Zone, South } \\
\text { West Ethiopia. Am J Heal } \\
\text { Res }\end{array}$ & Ethiopia & Quantitative & Cross-sectional & $\begin{array}{l}\text { School children } \\
\text { (grade 5-8) }\end{array}$ & 432 \\
\hline $\begin{array}{l}\text { Makoge V. } \\
2013\end{array}$ & $\begin{array}{l}\text { Status of malaria- } \\
\text { related knowledge in } \\
\text { school-going children in } \\
\text { Cameroon. }\end{array}$ & Cameroon & quantitative & Cross-sectional & $\begin{array}{l}\text { School children } \\
7-16 \text { years }\end{array}$ & 364 \\
\hline $\begin{array}{l}\text { Ayi, I. et al. } \\
2010\end{array}$ & $\begin{array}{l}\text { School-based participatory } \\
\text { health education for } \\
\text { malaria control in Ghana: } \\
\text { engaging children as } \\
\text { health messengers. Malar J }\end{array}$ & Ghana & Quantitative & $\begin{array}{l}\text { Quasi- } \\
\text { experimental }\end{array}$ & $\begin{array}{l}\text { School children } \\
\text { (grade 3-5) }\end{array}$ & 186 \\
\hline $\begin{array}{l}\text { Keating, J. } \\
\text { et.al. } 2012\end{array}$ & $\begin{array}{l}\text { A quasi experimental } \\
\text { evaluation of an } \\
\text { interpersonal communication } \\
\text { intervention to increase } \\
\text { insecticide-treated net use } \\
\text { among children in Zambia. } \\
\text { Malaria Journal. }\end{array}$ & Zambia & Quantitative & $\begin{array}{l}\text { Quasi- } \\
\text { experimental }\end{array}$ & $\begin{array}{l}\text { Children aged } \\
5-14 \text { years in } \\
\text { household }\end{array}$ & \\
\hline
\end{tabular}




\begin{tabular}{|c|c|c|c|c|c|c|}
\hline $\begin{array}{l}\text { Okoyo C. } \\
\text { et. al. } 2015\end{array}$ & $\begin{array}{l}\text { Comparing insecticide- } \\
\text { treated bed net use to } \\
\text { Plasmodium falciparum } \\
\text { infection among } \\
\text { schoolchildren living near } \\
\text { Lake Victoria, Kenya. Malar J }\end{array}$ & Kenya & Quantitative & Cross-sectional & School children & 5188 \\
\hline $\begin{array}{l}\text { Mathanga, } \\
\text { DP.et al. } \\
2015\end{array}$ & $\begin{array}{l}\text { The High Burden of Malaria } \\
\text { in Primary School Children } \\
\text { in Southern Malawi. Am J } \\
\text { Trop Med Hyg }\end{array}$ & Malawi & Quantitative & Cross-sectional & $\begin{array}{l}\text { School children } \\
\text { (5-21years: } \\
97.6 \% \text { under } 18 \\
\text { years) }\end{array}$ & 2623 \\
\hline $\begin{array}{l}\text { Tchinda, } \\
\text { VHM. } 2012\end{array}$ & $\begin{array}{l}\text { Factors associated to bed } \\
\text { net use in Cameroon: a } \\
\text { retrospective study in Mfou } \\
\text { health district in the Centre } \\
\text { Region. Pan Afr Med J }\end{array}$ & Cameroon & Quantitative & $\begin{array}{l}\text { Cross-sectional } \\
\text { (descriptive and } \\
\text { analytical) }\end{array}$ & $\begin{array}{l}\text { Households } \\
\text { (including data } \\
\text { on children and } \\
\text { adolescents } \\
\text { aged 5-24 years) }\end{array}$ & $\begin{array}{l}541 \\
\text { households }\end{array}$ \\
\hline $\begin{array}{l}\text { Hoshi, T. et } \\
\text { al. } 2013\end{array}$ & $\begin{array}{l}\text { Beyond buzzing: Mosquito } \\
\text { watching stimulates malaria } \\
\text { bednet use-a household- } \\
\text { based cluster-randomized } \\
\text { controlled assessor blind } \\
\text { educational trial. Emerg } \\
\text { Microbes Infect }\end{array}$ & Malawi & Quantitative & $\begin{array}{l}\text { Randomized } \\
\text { controlled } \\
\text { assessor blind } \\
\text { educational trial. }\end{array}$ & Households & 279 \\
\hline $\begin{array}{l}\text { Garley, } \\
\text { AE.et al. } \\
2013\end{array}$ & $\begin{array}{l}\text { Gender differences in the } \\
\text { use of insecticide-treated } \\
\text { nets after a universal free } \\
\text { distribution campaign in } \\
\text { Kano State, Nigeria: post- } \\
\text { campaign survey results. } \\
\text { Malar J }\end{array}$ & Nigeria & Quantitative & Cross sectional & $\begin{array}{l}\text { Individuals } \\
\text { including } \\
\text { adolescents }\end{array}$ & 4602 \\
\hline $\begin{array}{l}\text { Babalola, } \\
\text { S.et al. } \\
2016\end{array}$ & $\begin{array}{l}\text { Correlates of Intra- } \\
\text { Household ITN Use in } \\
\text { Liberia: A Multilevel Analysis } \\
\text { of Household Survey Data. } \\
\text { PLoS One }\end{array}$ & Liberia & Quantitative & Cross-sectional & $\begin{array}{l}\text { Households } \\
\text { (including data } \\
\text { on age group } \\
5 \text { - } 17 \text { years) }\end{array}$ & 1200 \\
\hline
\end{tabular}

Table 1 reveals the 14 identified studies from the literature search. Three people reviewed these studies including the author and 2 co-authors and an agreement was reached. The results revealed knowledge, attitudes and practice of malaria among schoolchildren in subSaharan Africa. Knowledge of malaria cause and transmission was ranging from $19.2 \%$ in Zimbabwe[20] to $85 \%$ in Nigeria,[16]however the age group of the schoolchildren in two countries were different. In Zimbabwe the schoolchildren were young (8-10 years) compared to those in Nigeria (11-20 years). There are still misconception of malaria cause and transmission in schoolchildren in many countries of Sub-Saharan Africa. Studies showed low to moderate level of practice of malaria prevention ranging from $32.4 \%$ in Malawi to $67.9 \%$ in Kenyan school children.
Some studies showed that boys use insecticide treated nets less likely than girls. Studies have been conducted in various countries of sub-Saharan Africa revealed the knowledge, attitude and practice of school children towards malaria. The reviewed studies were conducted in Cameroon,[21,22] Ethiopia,[23] Nigeria,[16,24,25] Tanzania,[26] Kenya,[7] Zambia,[27] Zimbabwe,[20] Malawi,[19,28] Liberia,[29] Ghana.[30] However, no study has been conducted in Rwanda regarding knowledge, attitude and practices of schoolchildren towards malaria prevention. 
The identified articles show the knowledge, attitudes and practice of schoolchildren towards the causes, signs of symptoms of malaria and management of malaria. The results of the review are discussed as follows:

\section{Knowledge of schoolchildren towards malaria}

Children attending school have baseline knowledge of malaria that they got from the courses based curricular. In a study done in Nigeria,[16] a high percentage $(85 \%)$ knew that malaria is caused and transmitted from one person to another through a mosquito bite. Another study conducted in the same country[25] also found that $77.5 \%$ of adolescents studying in secondary school knew the mode of transmission of malaria and $20 \%$ wrongly stated the mode of transmission as swallowing the parasite and sexual intercourse among others.[25] Recently, authors in Tanzania revealed 63\% of schoolchildren aged 6-14 years having knowledge on malaria transmission and recognized female "anopheles" as the only mosquito that can transmit malaria.[26] However, about 8\% of schoolchildren did not understand the type of mosquito that transmit malaria and 5.6\% had misconception about malaria transmission, some children know that malaria is caused by eating dirty food, contact with malaria patients and going to the toilet without shoes.[26] A study conducted in grade three schoolchildren aged 8-10 years in Zimbabwe revealed low knowledge of malaria cause. Only $19.2 \%$ knew the cause of malaria and most of the children (75\%) had no idea about malaria cause.[20] Misconception about malaria cause and transmission has also been found in schoolchildren in Ethiopia,[23] in Cameroon, [22] in Ghana[30] and in Nigeria.[16]

Some schoolchildren know that malaria can be caused by drinking dirty water.[16,22,23] Others know that eating dirty food can cause malaria and being in contact with malaria patient can also transmit malaria. $[16,23,26]$ Similarly in Ethiopia, flies were mistaken by students to be involved in transmission of malaria.[23] Misconception of malaria cause and transmission may be possibly due to adult community's perceptions. The adults may have spread these misconceptions towards malaria cause and transmission to schoolchildren from early childhood. False knowledge and misconceptions on causes of malaria will continue to increase the incidence and prevalence of this condition as well as related complications among the schoolchildren since they are not able to implement correct preventive measures of malaria. Therefore, this calls for urgent need to revisit the course based curriculum and make necessary changes so that the schoolchildren will be able to assimilate and comprehend correctly the causes of malaria. Furthermore, malaria knowledge should be spread at a regular basis in schools by health personnel to improve the knowledge base of the target population.

The most known symptoms of malaria are fever and headache reported by more than half of the respondents. $[22,26]$ Different findings have been found in Ethiopia, whereby approximately $30 \%$ of the participants reported fever as a symptom of malaria and the majority of them $(75.7 \%)$ mentioning feeling cold as a symptom of malaria.[23] Another study conducted in Nigeria found that only $32 \%$ of school adolescents reported fever as a symptom of malaria, $26.3 \%$ reported yellow urine and $21.6 \%$ reported headache as the symptom of malaria. Vomiting has been recognized as a symptom of malaria by $28 \%$ of the schoolchildren in Tanzania[26] and the same findings were reported in Ethiopia.[23] In a study conducted in Cameroon,[22] vomiting was reported by $37 \%$ of schoolchildren as a symptom of malaria. Few schoolchildren know the symptoms of malaria. Poor recognition of malaria manifestations may delay the time to seek treatment and care. This will eventually cause school absenteeism, reduced school performance as well as clinical complications such as cerebral malaria and acute kidney injury. The identified knowledge of malaria among school children is possibly due to inclusion of malaria curricular based courses in primary schools in sub-Saharan African countries. Again, the knowledge of malaria among Sub-Saharan school children may be linked to various channels of health communication including radio, television, organized drama and other social marketing activities. Despite the continual increase in prevalence of malaria and introduction of curriculum based malaria in Rwanda, the level of knowledge among these schoolchildren has not been studied.

\section{Attitude of schoolchildren towards malaria prevention}

The attitude of schoolchildren about malaria where $51.2 \%$ of the respondents strongly agreed that when they felt some symptoms of malaria, they should go to the nearest health facility for consultation and treatment instead of self-medication.[16] A study in Tanzanian school children aged 8-14 years revealed 80.8\% asking their parents to go to the health facility when they feel malaria symptoms while $15.2 \%$ of school children would ask their parents or guardians to get medicines from the medical stores when they feel sick from malaria.[26] The available literature shows few studies on attitude towards malaria prevention among school children in sub-Saharan Africa yet it is one of the factors directly influence the use of malaria preventive 
measures. Poor attitude of school children towards malaria possibly influence the low use of preventive measures. However, most KAP (knowledge, attitude and practice) studies conducted in school children lack the attitude component in detail; this is a gap to be filled in next researches in all countries which are malaria infested. Again, in the context of Rwanda, the variable of attitude has never been studied in school going age.

\section{Practices of schoolchildren towards malaria prevention}

Using mosquito net is the well-known method of prevention of malaria mentioned by $92 \%$ of schoolchildren in Tanzania,[26] $71 \%$ of students in Ethiopia[23] and $76 \%$ of school-going children in Cameroon.[22] More specifically in Southern Nigeria, $41.9 \%$ of school adolescents recognized that sleeping under insecticide treated bed nets (ITNs) is the strategy to prevent malaria.[16] In Malawi, of 2,667 schoolchildren, only $32.4 \%$ slept under a mosquito net the night before the survey and girls were more likely to use bed net compared to boys $(\mathrm{p}=0.047)$.[19] Similarly, only 37\% of schoolchildren aged 5-14 years in Zambia used the insecticide treated net before malaria campaign; the use of insecticide treated net increased from $37 \%$ to 67\% after campaign. [27] Low use of Insecticide treated nets in school-aged children (OR: 0.37) has also been reported in Cameroon,[21] Malawi,[28] Nigeria[24] and recently in Liberia.[29]

As children are becoming older and they are usually sleeping in separate bedrooms from the parents' with less parental control, their use of insecticide treated nets when they are sleeping is low; therefore strengthening health education on malaria prevention practices among schoolchildren would be potential way of prevention of malaria among school children. In Nigeria, 54.7\% of schoolchildren were using the ITN at the time of the survey[16] and in Kenya, 67.9\% of schoolchildren slept under a long lasting treated net the night prior to the survey.[7] However, other authors revealed poor practice of malaria preventive measures among schoolchildren in Nigeria as there were only $8.5 \%$ of school adolescents reported to use insecticide treated net.[25] In another study, clearing bushes around the house was used by $14.5 \%$ of the adolescent at the time of the study.[24]

Poor practice of malaria prevention may be linked to various factors as lack of follow-up during sleeping time and parental beliefs that children are becoming older.[21] The same authors argued that older children are usually sleeping in separate bedrooms from their parents which cause less usage of Insecticide treated net by this age-group. Similarly, another study echoed the same sentiments and explained that as children become older, they become independent and their parents are less controlling them when they go to bed and whether they sleep under a net or not.[3] Therefore, school-aged children and adolescents should be educated on malaria to increase the regular use of Insecticide treated nets. $[3,21]$ Regular use of malaria preventive measures such as sleeping under Insecticide treated nets is low in school children despite the efforts of malaria prevention in subSaharan African Countries such as free distribution of insecticide treated nets. Consequently, massive increase malaria incidence among this age group continues to have a negative impact on their school performance and if untreated, malaria complications may occur.

\section{Limitations}

- The authors used the time frame of studies from 2010 to 2016. Even though the time frame was wide, few studies were found during literature search. This may be due to poor malaria registry in sub-Saharan Africa; with some studies conducted but not published.

- The results can only be generalised to sub-Saharan African countries.

- The authors limited the review to only published articles written in English in sub-Saharan African countries. This might have introduced bias in that more valuable information might have been missed in other regions in the world where malaria is more prevalence among schoolchildren.

\section{Conclusion}

Despite the introduction of curricula based malaria course and education awareness programmes among school children, Knowledge, attitude and practice of malaria prevention remain a pervasive problem in different countries of sub-Saharan Africa. The available literature identified knowledge of schoolchildren to be moderate whereas the attitude was low whilst the practice of malaria prevention was also low in schoolchildren. These findings were found in fewer published articles from countries of Sub-Saharan Africa including namely East Africa, West Africa, Central Africa and Southern Africa and this calls for the need for further research, encouragement of peer reviewed publications as well as improved malaria registry in underdeveloped subSaharan countries where malaria cases are dramatically increasing. Again, research on knowledge, attitude 
and practice of malaria in schoolchildren is needed in Rwanda since this is a curricular based course. Moreover, knowledge of malaria should be reinforced in this particular age-group to alter the perceptions in a positive way. This will consequently improve the preventive practices of malaria thus reducing the overall malaria incidence and prevalence and related complications and consequences in schoolchildren.

\section{References}

1. Gething PW, Patil AP, Smith DL, Guerra CA, Elyazar IRF, Johnston GL, et al. A new world malaria map: Plasmodium falciparum endemicity in 2010. Malar J [nternet]. BioMed Central Ltd; 2011;10:378. Available from: http://www.malariajournal.com/ content/10/1/378

2. Murray C, Rosenfeld L, Lim S, Andrews K, Foreman $\mathrm{K}$, Haring D, et al. Global malaria mortality between 1980 and 2010: a systematic analysis. Lancet. 2012;379:413-31.

3. Brooker S, Clarke S, Fernando D, Gitonga CW, Schellenberg D, Greenwood B. Malaria in SchoolAge Children. Child Adolesc Dev. 2014. p. 319-54.

4. Ghansah A, Amenga-etego L, Amambua-ngwa A, Andagalu B, Bouyou-akotet M, Cornelius V, et al. Monitoring parasite diversity for malaria elimination in sub- Saharan Africa. Science (80- ). 2014;345:1297-8.

5. Clarke S, Diarra S, Bamadio M, Jones R and others. The impact of intermittent parasite clearance on malaria, anaemia and cognition in school children: New evidence from an area of highly seasonal transmission. Trop Med Int Heal. 2013;18.

6. Nankabirwa J, Wandera B, Kiwanuka N, Staedke SG, Kamya MR, Brooker SJ. Asymptomatic Plasmodium infection and cognition among primary school children in a high malaria transmission setting in Uganda. Am J Trop Med Hyg. 2013;88:1102-08.

7. Okoyo C, Mwandawiro C, Kihara J, Simiyu E, Gitonga CW, Noor AM, et al. Comparing insecticidetreated bed net use to Plasmodium falciparum infection among schoolchildren living near Lake Victoria, Kenya. Malar J. 2015;14:515.

8. Rehman AM, Coleman M, Schwabe C, Baltazar G,
Matias A. How much does malaria vector control quality matter: The epidemiological impact of holed nets and inadequate indoor residual spraying. PLoS One. 2011;6.

9. Kimbi HK, Sumbele I., Nweboh M, Anchang-Kimbi JK, Lum E. Malaria and haematologic parameters of pupils at different altitudes along the slope of Mount Cameroon: A cross sectional study. Malar J. 2013;12.

10. Ibara-Okabande R, Koukouikila-Koussounda F, Ndounga M, Vouvoungui J, Malonga V. Reduction of multiplicity of infections but no change in msp2 genetic diversity in plasmodium falciparum isolates from congolese children after introduction of artemisinin-combination therapy. Malar J. 2012;11.

11. Clarke S, Roschnik N, Rouhani S, Diarra S, Bamadio M, Sacko M, et al. Malaria in school children under a new policy of universal coverage of nets: Recent data from Mali and Senegal. Am J Trop Med Hyg. 2012;87:445.

12. Assi SB, Henry MC, Rogier C, Dossou-Yovo J, Audibert M. Inland valley rice production systems and malaria infection and disease in the forest region of Western Cote d'Ivoire. Malar J. 2013;12.

13. Ojurongbe OA, Adegbayi AM, Bolaji OS, Akindele AA, Adefioye OA, Adeyaba OA. Asymptomatic falciparum malaria and intestinal helminths coinfection among school children in Osogbo, Nigeria. J Reasearch Med Sci. 2011;16:680-6.

14. Ashton RA, Kefyalew T, Tesfaye G, Pullan RL, Yadeta D. School-based surveys of malaria in Oromia regional State, Ethiopia: A rapid survey method for malaria in low transmission settings. Malar J. 2011;10.

15. Schumacher R-F, Spinelli E. Malaria in children. Mediterr J Hematol Infect Dis. 2012;

16. Eko Jimmy E, Osonwa Kalu O, Offiong Dominic A. Practices of Malaria Prevention among School Adolescent within Calabar Metropolis, Southern Nigeria. J Sociol Res. 2013;4:241-55.

17. Nankabirwa J, Brooker SJ, Clarke SE, Fernando D, Gitonga CW, Schellenberg D, et al. Malaria in school- 
age children in Africa: An increasingly important challenge. Trop Med Int Heal. 2014;19:1294-309.

18. Chen I, Clarke SE, Gosling R, Hamainza B, Killeen G, Magill A, et al. "Asymptomatic" Malaria: A Chronic and Debilitating Infection That Should Be Treated. PLoS Med. 2016;13:1-11.

19. Mathanga DP, Halliday KE, Jawati M, Verney A, Bauleni A, Sande J, et al. The High Burden of Malaria in Primary School Children in Southern Malawi. Am J Trop Med Hyg. 2015;93:779-89.

20. Midzi N, Mtapuri-Zinyowera S, Mapingure MP, Paul NH, Sangweme D, Hlerema G, et al. Knowledge attitudes and practices of grade three primary schoolchildren in relation to schistosomiasis, soil transmitted helminthiasis and malaria in Zimbabwe. BMC Infect Dis. BioMed Central Ltd; 2011;11:169.

21. Tchinda VHM, Socpa A, Keundo AA, Zeukeng F, Seumen CT, Leke RGF, et al. Factors associated to bed net use in Cameroon: a retrospective study in Mfou health district in the Centre Region. Pan Afr Med J. 2012;12:112-22.

22. Makoge V, Ndzi E, Mbah G, Nkengazong L, Moyou $\mathrm{R}$, Makoge V. Status of malaria-related knowledge in school-going children in Cameroon. Arch Appl Sci Res. 2013;5:105-11.

23. Debela Y. Malaria Related Knowledge and Child to Parent Communication Regarding Prevention and Control of Malaria among Primary School Students in Jimma Zone, South West Ethiopia. Am J Heal Res. 2014;2:284.

24. Garley AE, Ivanovich E, Eckert E, Negroustoueva $\mathrm{S}$, Ye Y. Gender differences in the use of insecticidetreated nets after a universal free distribution campaign in Kano State, Nigeria: post-campaign survey results. Malar J. 2013;12:119.

25. Udonwa N, Gyuse A, Etokidem A. Malaria: Knowledge and prevention practices among school adolescents in a coastal community in Calabar, Nigeria. African J Prim Heal care \&Family Med. 2010;2.

26. Sumari D, Dillip A, Ndume V, Mugasa JP, Gwakisa PS. Knowledge, attitudes and practices on malaria in relation to its transmission among primary school children in Bagamoyo district, Tanzania. Malar World J. 2016;7:1-7.

27. Keating J, Hutchinson P, Miller JM, Bennett A, Larsen DA, Hamainza B, et al. A quasi-experimental evaluation of an interpersonal communication intervention to increase insecticide-treated net use among children in Zambia. Malar. J. 2012. p. 313.

28. Hoshi T, Banda PM, Pemba DF, Sunahara T, Minakawa N. Beyond buzzing: Mosquito watching stimulates malaria bednet use-a householdbased cluster-randomized controlled assessor blind educational trial. Emerg Microbes Infect. 2013;2:1-6.

29. Babalola S, Ricotta E, Awantang G, Lewicky N, Koenker H, Toso M. Correlates of Intra-Household ITN Use in Liberia: A Multilevel Analysis of Household Survey Data. PLoS One. 2016;11.

30. Ayi I, Nonaka D, Adjovu JK, Hanafusa S, Jimba M, Bosompem KM, et al. School-based participatory health education for malaria control in Ghana: engaging children as health messengers. Malar J. 2010;9:98. 